\title{
Socialvetenskapen och de sociala problemen
}

\author{
GUNNAR OLOFSSON
}

Denna artikel diskuterar "de sociala problemens" roll för sociologin och socialvetenskapen. Socialvetenskapens uppkomst är knuten till hanteringen av sociala problem, $i$ betydelsen existens- och försörjningsproblem som industrialismen och urbaniseringen medförde för arbetarklassen och de fattiga. Socialvetenskapen bidrar med en särskild form för tillämpbar kunskap; den utvecklar "reformobjekt", som binder ihop förklaring med ingrepp. Detta visas i en diskussion av levandsnivåforskningen. Till sist diskuteras förhål-

landet mellan socialvetenskapen som åtgärdssökande kunskap om sociala problem och synen på sociala problem som frambringade av myndigheters åtgärder.

\section{Den usociala frågan" och sociologins uppkomst}

Sociologin är en vetenskap om "det sociala» $\mathrm{i}$ två avseenden. Den är dels en generell samhällsteori och dels systematisk empirisk kunskap om sociala förhållanden. Med detta dubbla perspektiv kan sociologin som disciplin förankras i olika sammanhang. När vikten läggs vid sociologins begreppsliga struk-

Gunnar Olofsson, sociolog från Lund, forskar om den äldre arbetskraften på arbetsmarknaden med stöd från SFR och om förhållandet mellan ojämlikhet och integration i Skandinavien och USA inom "Center for Social Integration og Differentiering" vid Handelshögskolan i Köpenhamn. tur betonas förhållandet till andra filosofiska och samhällsvetenskapliga teoribildningar. Exempelvis kan det gälla dess förhållande till marxismen och nationalekonomin (t.ex. Zeitlin 1968, Therborn 1976, Sörensen 1982). Nisbet ser sociologins centrala begrepp som det konservativa tänkandets svar på den franska revolutionens erfarenhet (Nisbet 1967). Men sociologins begreppsliga utveckling kan också behandlas som en intern vetenskaplig och filosofisk process, där framväxten av nya begrepp främst analyseras i relation till tidigare författares begrepp (Parsons 1937, Habermas 1981).

En analys av sociologins uppkomst och 
historia kan för det andra betona dess roll som vetenskapliggjord kunskap om "sociala problem « med inriktning på en problemlösande praxis (Oberschall 1972, Kern 1982, Hinkle \& Hinkle 1954, Hinkle 1980, Schwendinger \& Schwendinger 1974). Detta perspektiv betonar att disciplinens metodologi och dess teoretiska begrepp utvecklas parallellt med den problemorienterade empiriska forskningen (Wagner 1990, Oberschall 1965, Hinkle 1980, Madge 1962).

I ett sådant perspektiv blir Rowntrees empiriska undersökningar av fattigdomen i York för en förståelse av den engelska samhällsvetenskapen viktigare än Herbert Spencers omfångsrika, men nu bortglömda sociologiska arbeten om den sociala differentieringen (jfr Abrams 1968).

På samma sätt framstår i Tyskland de energiska katedersocialisterna kring Verein für Sozialpolitik (VfS) med omfattande socialpolitiska kartläggningar som centrala för tysk samhällsforsknings uppkomst och utveckling. VfS är viktig i sig självt och bör således inte bara betraktas som en arena för Max Webers samhällsengagemang (jfr Mitzman 1973, Oberschall 1965, Ringer 1979, Therborn 1976, Wagner 1990).

Gustaf af Geijerstams utredningar om levnadsvillkoren i Stockholm eller Emigrationsutredningens rapporter blir i samma perspektiv kanske mera relevant som exempel på tidig svensk sociologi än de nu bortglömda akademiska arbeten som skrevs av landets förste professor i sociologi, Gustaf Steffen (jfr Gullberg 1972, Fridjónsdóttir 1987 och 1990, Lilliestam 1960)

I England, Tyskland och Frankrike hade man redan under 1700-talet börjat att sys- tematiskt samla in uppgifter om befolkningens storlek, sammansättning och levnadsförhållanden.(Oberschall 1972, IESS 1968). Detsamma gäller i Sverige Tabellverket från 1749 , som senare blev Statistiska centralbyrån. Syftet med denna offentliga statistik var att ge ett bättre underlag för statens verksamhet (jfr Heinsohn \& Steiger 1982).

\section{Socialpolitik och arbetarrörelse}

Under slutet av 1800-talet debatterades i Europa narbetarfrågan« eller som den också kallas, den "sociala frågan" (Lange 1875, Sombart 1908, Castel 1995). Den blev direkt och indirekt en viktig förutsättning för framväxten och institutionaliseringen av sociologin i Europa.

Den omvälvning som kapitalismen medförde för det rådande samhällssystemet i Europa och Amerika under 1800-talet innebar en påskyndad omdaning av alla samhälleliga förhållanden; gamla sociala mönster bröts upp, nya formades $i$ allt snabbare takt. Gamla trygghetssystem i form av familj, släkt och lokala arrangemang omvandlades snabbt (Polanyi 1944/1989) och nya socialpolitiska institutioner utvecklades; det gällde allt ifrån organiseringen av sjuk- och begravningskassor till statens lagstiftning om arbetarskydd. ${ }^{1}$

Gamla samhälleliga problem gavs nya former. De fattigas och egendomslösas problem

\footnotetext{
I ett annat sammanhang diskuterar jag olika analyser av socialpolitikens uppkomst och institutionalisering och de krafter som burit fram den (Olofsson kommande). Där tar jag upp diskussionen om välfärdsstatens uppkomst, om vilka sociala krafter som burit fram och format den, och går in på klass-, maktresurs- och riskgrupps-ansatserna.
} 
förvandlas gradvis till lönearbetarnas försörjningsproblem. (jfr Olofsson 1979 och, 1995, Castel 1995). Underklassens sociala villkor blev så småningom (industri-)arbetarklassens problem. I konstitueringen av industriarbetargruppen till en arbetarrörelse formades krav och utvecklades förslag till lösningar.

Vi kan här urskilja olika principiella slag av ingrepp och reaktioner: reglering av sociala förhållanden via lagstiftning; uppbyggnad av nya organ och institutioner för att genomföra beslutade åtgärder; problemhantering via självorganisering $i$ kassor men också framväxten av olika samhällsgruppers och intressens krav på åtgärder från statens sida (jfr Polanyi 1994/1989).

De offentliga institutionerna ställdes inför problem som följde av lönearbetarexistensens problematiska villkor. Det sätt varpå det gjordes och vilka reaktioner och ingrepp som blev resultatet påverkades till form, omfång och innehåll av löntagarnas fackliga och politiska mobilisering. Filantropi och fattighjälp omvandlades så småningom till generella offentliga socialpolitiska ingripanden och en stegvist professionaliserad socialarbetarpraxis.

\section{Social forskning i Europa}

I den europeiska verkligheten och tänkandet gav denna våldsamma omstrukturering och dess mänskliga konsekvenser inte bara upphov till självorganisering och offentliga ingripanden utan också till framväxten av nya hanteringssätt och nya former för vetande

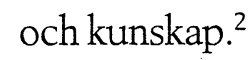

2 De sociologiska klassikerna Marx, Durkheims och Webers teorier kan ses som tre skilda sys-
I Europa uppkom tidigt en mångfacetterad arbetarrörelse. Här utvecklades också en serie socialpolitiska ingripanden och regleringar, främst i form av socialförsäkringar (jfr Alber 1982). I Europa fanns en samtidighet mellan upptäckten av »de sociala problemen« och framväxten av arbetarrörelsen och socialismen.

Det fanns ett nära inre samband i det sätt varpå de europeiska staterna kom att se på de sociala problemens lösning. Arbetarrörelse och socialpolitik var två olika svar på industrialismens nya - eller förnyade - former för socialitet respektive fattigdom och elände. De hade en gemensam rot i lönearbetarexistensens både specifika och allmänna levnadsvillkor. Arbetarrörelsen växte fram som organisatoriska och sociala praktiker visavi marknadssamhällets former och som instrument för lönearbetarnas krav och intressen. Dess krav riktade sig mot andra klasser och skikt och gentemot stat och kommun (jfr Olofsson 1979 och 1995).

Den framväxande statliga socialpolitiken var i sin mest generella form ett försök att lösa den moderna lönearbetarexistensens försörjningsproblem genom lagstiftning, socialförsäkringar och strävan att främja arbetarklassens integration och inordning i den rådande samhällsordningen. Existensrisker och försörjningsproblem sökte man lösa som ett politiskt-sociologiskt problem, som ett integrationsproblem. Med en ofta an-

tematiska samhällsvetenskapliga förklaringar på industrialismens omvandling av samhällsstruktur och existensformer (jfr Abrams 1982: kap 2-4). Diagnoserna, förklaringarna, de förespråkade lösningar liksom de centrala begrepp de utvecklade skiljer sig åt, men föremålet för teorierna är i en mening det samma. 
vänd formulering så var ett mål för den tyska socialpolitiken i Bismarcks tappning att göra socialismen överflödig.

\section{Sociala problem och social forskning i USA}

Den amerikanska sociologin växer från 1890-talet fram mot bakgrund av storstädernas slum, ungdomskriminaliteten, upplösningen av den sociala kontrollen, familjesönderfallet etc. (Hinkle 1980, Schwendinger \& Schwendinger 1974). IUSA kom immigrationen, urbaniseringen och proletariseringen att förstås som grunden till de "sociala problemen" - dvs de former för sönderfall, elände, oordning och upproriskhet som var karakteristiska för det snabbt förändrade amerikanska samhället under 1800-talets slut. Den i USA framväxande "socialpatologin« eller som det senare kom att heta "studiet av sociala problem" handlade om dessa förhållanden (jfr C.W. Mills 1943/ 1963, Merton \& Nisbet 1961 m.fl.)

De tidiga amerikanska forskare och intellektuella som kom att utveckla det samhällstänkande som blev till sociologi förklarade de rådande sociala problemen med upplösningen av de normer och av den kontroll varmed stabila och välfungerande grupper och närmiljöer hittills uppfångat de potentiellt avvikande grupperna och beteendena. Det centrala botemedlet var uppfostran och omfostran genom att förstärka gamla institutioner som familjen men också konstruktionen av nya institutioner för att kunna hantera de upplösande mekanismerna. Dvs lösningen på de sociala problemen i ett amerikanskt (storstads)sammanhang sågs i form av en utökad och förändrad social kontroll. Konkret hölls lösningarna i USA på en lokal eller delstatlig nivå, och inte främst på statlig nivå som $i$ Europa.

Det blev mer av stadens än statens problem, mera kommunalt socialt arbete än övergripande statliga lösningar i t.ex. socialförsäkringarnas form. I USA gav de nya problemen upphov till en reformpraxis, inriktad på normativ påverkan.

Den tidiga amerikanska sociologin betonade begrepp som norm, primär- och sekundärgrupp, primär och sekundär socialisering. Denna typ av kunskap, och mera precist den begreppsvärld av bestämningsfaktorer och sociala mekanismer var i princip möjlig att använda för att identifiera och diagnosticera de problem som klassificerats som "sociala problem". Men detta innebär å andra sidan inte att giltigheten och generaliserbarheten av dessa begrepp och denna kunskap skulle vara begränsade till dess uppkomstbetingelser (se Mills 1943/1963, Hinkle 1980; jfr även Österberg 1988).

\section{Från identifikation av problem till lösning genom myndighetshandlande}

1800-talets snabba omvandling av samhället, genom urbanisering, industrialisering och migration skapade nya och problematiska omständigheter, inte minst för de lägre skikten och de fattiga. Trycket på de traditionella försörjningssystemen ökade. Fattigvårdslagstiftningen skärptes i många länder. Vilka grupper var t.ex. oförskyllt fattiga och vilka skulle ha rätt till understöd?

De sociala förhållanden och erfarenheter som ämbetsmän och opinionsbildare i olika länder såg som "sociala problem" kunde emellertid inte som regel hanteras av existe- 
rande myndigheter med deras givna verksamhetsformer. Ibland kunde nya problem hanteras genom att de inordnades under en redan given kategori, t.ex. genom att tänja eller utvidga den. Men i regel krävdes det att ett problem för att kunna hanteras identifierades skarpare genom en avgränsning eller genom att skapa en ny klassifikation. Ett centralt exempel är här den successiva framväxten av begreppet "arbetslöshet» med alla de konsekvenser detta fătt för att kunna skilja ut olika grupper med olika slags försörjningsproblem och därför med olika grad av rättigheter och anspråk på offentligt stöd till sin utkomst (Garraty 1978).

I detta läge växte den administrativa och politiska betydelsen av en ny slags kunskap, dvs kunskaper om vari de nya problemen och omständigheterna bestod, hur de uppkommit och vari de hade yttrat sig, hur de kunde mätas, om de ökade eller minskade etc.

Det var nya offentliga institutioner som blev viktiga producenter av administrativa eller kartläggande data, data som i sin tur kom att tjäna som underlag för kunskapsutveckling. Ett berömt tillfälle i samhällsvetenskapens historia är att Marx som bekant flitigt använde de rapporter som de engelska fabriksinspektörerna sammanställde över läget $\mathrm{i}$ den engelska industrin för sin framställning i Kapitalet. Men också de framväxande socialförsäkrings-organens verksamhet gav tidigt upphov till systematiska datainsamlingar, uppgifter som behövdes för förvaltningen av dessa system (Kern 1982, Abrams 1968, Oberschall 1965 och 1972, IESS 1968).

Expansionen av den rationella byråkratiska organisationen av statens och städer- nas förvaltning ledde till en systematisk insamling av statistik om sociala förhållanden. Samtidigt ökade den politiska elitens och statens förlitan på kunskap och systematiskt vetande för att lösa olika slags problem. Därigenom uppkom det "rum" och det utrymme för nya slags kunskaper - och kunskapsformer - om det moderna livets och den moderna socialitetens risker och problem som den empiriska probleminriktade sociologin kom att utvecklas inom.

Den systematiska kunskapen om lönearbetarnas sociala förhållanden inom produktionens sfär och de lägre klassernas problem i den församhälleligade reproduktionens sfär, vad som bestämmer och reglerar dem, och hur den offentliga sektorn har kommit att fungera i förhållande därtill, kan på ett innehållsligt plan sägas vara "sociologins rum«, såväl för dess användning som för dess teori.

\section{Svensk sociologi som reformvetenskap}

En konklusion av det som sagts ovan är att den empiriska socialvetenskapen inklusive sociologin begreppsligt och med sina metodiska verktyg bearbetar problematiska eller icke önskvärda sociala förhållanden på ett sådant sätt att man kan begripa dem som "sociala problemu. Detta är inte en värdering av att socialvetenskapen bör eller skall göra det, utan det är ett historiskt grundat konstaterande av vad den i huvudsak tycks ha gjort. Låt oss pröva detta resonemang på den moderna svenska sociologins framväxt.

En bakgrund till att sociologin tidigt under efterkrigstiden fick plats vid svenska universitet var förhoppningen att ämnet 
skulle kunna tjäna som reformvetenskap i välfärdsbygget (Fridjónsdóttir 1987 och 1990, Gullberg 1972). Sociologin sågs som en reform- och planeringsvetenskap, som den reformerande politikens och byråkratins hjälpmedel. ${ }^{3}$ Upptagenheten av de sociala problemen och deras möjliga lösning var i Sverige viktig för den moderna sociologins framväxt (jfr redan Myrdal \& Myrdal 1934).

Ser vi till den forskning som bedrivits inom svensk sociologi så har sådana förhoppningar också infriats. ${ }^{4}$ Svenska sociologer har ofta analyserat effekterna och konsekvenserna av statens och de offentliga organens ingripande i de sociala förhållandena. Det kan gälla skolpolitiken och skolre-

3 Det var inte bara en fråga om sociologin. Också statskunskapen, kulturgeografin (där inte minst tidsgeografin blev en viktig planeringsvetenskap) och pedagogiken kunde vara ett argument för utvidgningen av statliga uppgifter och utgifter och instrument för samhällsomvandling. Det gällde i hög grad nationalekonomin. Utifrån såväl planeringskeynesiamens och cost-benefit-traditionen kunde omfattande offentliga arrangemang motiveras. Ett exempel är de samhällsekonomiska argumenten för utbyggnaden av den offentliga barntillsynen och daghemmen. Visserligen var daghemmen dyra. De ökade löner som kvinnor kunde få om de hade en obruten arbetskarriär, och de högre livslöner som kvinnor därigenom skulle få och de skatter som dessa skulle ge upphov till blev starka argument för utbyggnaden.

4 Jag tar i denna artikel inte upp industrisociologin, arbetslivsforskningen, forskningen om medinflytande och fabriksnedläggningar, om arbetslöshet, arbetsmarknad och arbetsmarknadspoilitik, eller om planering, boende och bebyggelse. Dessa områden är exempel på viktiga fält och områden som ytterligare skulle bekräfta den bild som här ges av den sociala forskningen i mera avgränsad mening. formernas betydelse för den sociala sammansättningen och skolresultat bland eleverna (Arnman \& Jönsson 1983, 1986; Erikson \& Jonsson 1994). Skillnader i levnadsvillkor har undersökts från det tidiga 1970-talets låginkomstutredning till dagens levnadsnivåundersökningar (S. Johansson 1970a, 1970b, 1970c, 1971, Lena Johansson 1970, 1971, Ahrne 1971, Erikson 1971; vidare Erikson \& Åberg 1984 och Fritzell \& Lundberg 1993 och 1994). Sociologer har utforskat fängelsernas roll som straff och anpassningsorgan (Bondesson 1974) liksom socialtjänsten och dess förhållande till klienterna (Sunesson 1981,1985).

Några områden har efter hand utvecklats till egna specialområden. Kriminologer inriktar sig mot brott/straff/fängelse-komplexet. Den i Sverige nya disciplinen socialt arbete tar sig an socialvårdens och socialtjänstens område medan rättssociologer utvärderat t.ex. jämställdhetslagstiftning (Widerberg 1980) och socialförsäkringar (Hetzler-Eriksson 1983) eller diskuterar rättens sociala roll liksom ramlagstiftningens roll som styrinstrument etc (Hydén 1978 och 1984).

1970-talets förskole-, familje- och prostitutionspolitik kom att motiveras bl.a. utifrån Rita Liljeströms bidrag till skilda offentliga utredningar (Liljeström 1973 och 1975 resp. Ds 1980:9). Upptagenheten av universitetens sociala selektion kom till uttryck i Bengt Gessers bidrag till U 68-utredningen (Gesser 1971) och har utgjort ett återkommande inslag i senare utredningar om skol- och universitetspolitiken (Erikson \& Jonsson 1994; jfr Gesser 1985 för en diskussion om problemets beständighet).

Vandalism, multiproblemfamiljer, in- 
vandring, främlingsfientlighet, hemlöshet och vräkningar, bostadssegregation, alkoholoch narkotikamissbruk, nyfattigdomen, socialbidragens roll, fosterbarnens villkor, kvinnomisshandel, videovåld, hemtjänstens arbete och organisation etc har varit viktiga områden för empirisk socialforskning under de senaste decennierna. Det är en forskning som i många fall gett viktig kunskap om problematiska sociala förhållanden. Men hur kan då den tillämpade sociala forskningen fungera i förhållanden till de åtgärdande myndigheterna?

\section{Från sociala problem till skapandet av reformobjekt}

Den tillämpade sociala forskningen spelar en viktig roll för att som led i formuleringen och diagnosen av isociala problem « utveckla de begreppsliga redskap som gör det möjligt att analysera och omformulera dem, t.ex. med nya avgränsningar och klassifikationer av personer, motiv, beteenden, handlingar och av de åtgärder, ingripanden och institutioner som finns eller skapas för att ingripa och hantera dem. Jag föreslår här att vi definierar dessa tankemässiga operationer som att den sociala forskningen härigenom skapar "reformobjekt". Det innebär mera precist följande

(a) Utifrån myndighetens perspektiv ges socialt problematiska förhållanden formen av "sociala problem». Därigenom blir de möjliga att samtidigt begripa och angripa.

(b) Den tillämpade socialvetenskapen producerar å ena sidan nya kunskaper, inkl. nya teorier, mätinstrument etc och å andra sidan också (c) möjliga ingreppsformer visavi de sociala problemen.

(d) Reformobjektet är således ett strategiskt mellanled mellan å ena sidan konstaterandet av icke önskvärda tillstånd och ingripandet visavi dem.

Ett exempel på intellektuella operationer som gör det möjligt att konceptualisera problem på ett nytt och ingreppsrelevant sätt är t.ex. kartläggningar och undersökningar av socialbidragstagare som syftar till att avgränsa olika grupper bland som söker socialbidrag så att hanteringen av dem blir lättare att göra. Detta är ett exempel på den enklaste nivån, dvs begreppsliga operationer för att ändra formen för klassifikation av personer och handlingar och för en åtgärdsrelevant indelning av en problemgrupp i skilda undergrupper (som underförstått får olika behandling och bemötande).

\section{Reformobjekt och policy-relevans}

Vetenskapssociologiskt är det okontroversiellt att hävda att kontexten och den institutionella miljön påverkar vilka frågor som ställs, eller att dessa styrs av forskares värderingar. Men när jag här säger att tillämpad samhällsforskning producerar "reformobjektı implicerar detta emellertid också att det är en särskild slags metodologi, teori och vetenskapssyn som åberopas.

En nära förbindelse mellan eftersträvad förklaring och åtgärdsmöjligheten inverkar också på den typ av kunskap som produceras eftersom den i princip formas av kravet att vara ingreppsrelevant. Själva användbarheten av samhällsvetenskap sägs t.o.m. vara dess demokratiska signum. Vetenskapsfilosofen Poppers krav på att samhällsvetenskapen skulle möjliggöra ett stegvist reformar- 
bete, "piecemal social engineering" ligger under aktuella pläderingar för den värdeoch policy-relevanta samhällsforskningen (jfr Forskningsberedningen 1996).

Den koppling mellan förklaring och åtgärd som finns i den här anförda typen av socialvetenskap får till konsekvens att den $\mathrm{i}$ relation till „det sociala problemet« konstruerar ett "reformobjekt», som skall göra det möjligt för myndigheter att handla på ett för dem relevant sätt. Det kan vara fråga om många slags handlande (eller icke-handlande) som har till avsikt att övervinna, bearbeta, överskyla eller eliminera de sociala tillstånd, som man sett som problematiska och icke önskvärda. Det kan vara fråga om kunskap och vetande som tar sikte på olika slags användare och brukare; det jag benämnt "reformobjekt" är anpassat till myndigheter och offentliga organ. ${ }^{5}$

Ett exempel på hur "reformobjekt» utformas är följande. Vissa problem kan antas gälla för stora grupper av medborgare, t.ex. alla lönearbetare. Det gäller sjukdom, arbetsskada, invaliditet, arbetslöshet och död. Dessa typer av problem kan begreppsliggöras som risker för individer och risksannolikheter inom en grupp, mätas med statistik och lösas och hanteras genom försäkringar. De ses som strukturella problem och lösningen kan ligga $i$ ändrade rättsregler, institutioner, generella bidrag etc. Andra typer av "sociala problem" lokaliseras och begreppsliggörs i stället som individuella problem och tillskrivs individers egenskaper eller förhållanden. Det gäller alkoholdrickan-

5 Men kunskap och vetande kan också utformas i relation till andra adressater som olika intresseorganisationer, väljare eller t.o.m. medborgare. Jfr konklusionen nedan. de och andra former för drogbruk (kategorier som missbruk och beroende), barn- och hustrumisshandel, pedofili, kriminalitet m.m.

\section{Från "problem" via "reformobjekt" till "lösning"}

Samhällsvetenskapliga kartläggningar av sociala förhållanden kan leda fram till identifikation av samhälleliga och socialpolitiska problem. Detta slag av kunskapssystematisering lägger myndighetshandlandet tillrätta. Den skapar en vetande-åtgärdssekvens av rationalistisk typ (jfr nedan).

Diagnosen av problemen och de önskvärda målen binds samman med hjälp av klassifikationer och åtgärder. Via lagstiftning och ändringar i fördelningen av resurser går vägen från oönskade till önskade tillstånd. Vägen från problem via ingrepp till åsyftat resultat förmedlas av en stat som inte fungerar enbart reaktivt, utan också förebyggande och föregripande.

Begreppsliggörandet av de icke önskvärda sociala förhållanden som "sociala problem» är det första steget. Kopplingen av förklaringen till problemets orsaker och förekomst till lösning och åtgärd sker via det jag kallat "reformobjekt». Vi kan belysa detta med ett fall.

\section{Från fattigdom till levnadsnivå}

Forskning kring levnadsförhållanden och sociala indikatorer är ett viktigt exempel på tillämpad socialvetenskaplig forskning under 1960- och 1970-talen. Denna forskning var nära knuten till en ingripande politik för utjämning av levnadsstandard och med en ambition om planerat problemförhindrande. Politiskt bars den främst fram av social- 
liberala och socialdemokratiska strömningar. Det var i de nordiska länderna och i England som den tillämpade socialforskningen fick denna inriktning och det var här man institutionaliserade levnadsnivåforskningen. Fattigdomskriget, stheWar on Poverty «i USA under 1960-talet gav å sin sida upphov till en annan ny vetenskaplig disciplin, evalueringsforskningen, eftersom tyngdpunkten här låg på att pröva hur olika slags lösningar och åtgärder verkade, och att finna vilka som var kostnadseffektiva.

I Sverige blev Låginkomstutredningen exponent för denna del av den tillämpade socialforskningen. Den utredningen började sitt arbete i mitten av 1960-talet. ${ }^{6}$ Dess forskningsansats och metodik kom senare att institutionaliseras i levnadsnivåundersökningarna vid Institutet for social forskning (SOFI), där man också upprepade och vidareutvecklade den ursprungliga undersökningen från 1968 under åren 1974, 1981 och 1991. Ett annat arv från Låginkomstutredningens ansats är Statistiska Centralbyråns undersökningar av levandsförhållandena(ULF).

Den svenska låginkomstutredningen förfinade analysen av maskorna i den socialpolitiska trygghetsväven. ${ }^{8}$ Den strategiska re-

6 De viktigaste bidragen för sociologin var serien av kartläggningar av levnadsvillkoren, som publicerades som s.k. utkast till kapitel.

7 Statistiska centralbyrån utvecklat och genomfört en lång rad undersökningar som har redovisats i en rad rapporter i en serie om »Levnadsförhållanden«. Se t.ex. en sammanfattning från mitten av 1980-talet i Vogel 1987a och $1987 b$.

8 Liknande undersökningar genomfördes i flera andra länder, t.ex. i Danmark med »Lavind- formpolitiska poängen med den empiriska kartläggningen i Låginkomstutredningen var att den med enkla grepp i princip kunde översättas till en reformkatalog. När man i en korstabell kombinerar kön, klass, bostadsort och ett välfärdsproblem så ger redan en sådan beskrivande fördelning uppslag till reformpolitiska förändringar och ingripanden.

Låt mig ta ett exempel med personlig bakgrund på forskning i samhällsförbättrandets tjänst. Under 1967 arbetade jag som ung sociolog vid Låginkomstutredningens kansli. En diskussion med en äldre kollega gjorde ett starkt intryck. Själv var jag med min sociologiska skolning inställd på att analysera de kausalt intressanta förhållandena och ville se fördelningen av goda och onda villkor i relation till en strukturell ram. Det viktiga för mig var att förklara levnadsvillkorens fördelning och förändring över tid i olika samhällsklasser och knyta detta till samhällsstrukturens bärande lag (arbete, egendom, utbildning etc). Detta kunde nog vara intressant, genmälde min kollega. Men var det inte viktigare att skapa en finfördelad välfärdsstatistik som också kunde leda till att de problem man därigenom blev förmögen attlokalisera också blev möjliga att konkret hantera? Detaljerad empirisk kunskap skulle göra det möjligt att utforma träffsäkra sociala reformprogram. Om man t.ex. kan lokalisera de grupper som hade problem med sina tänder efter administrativt hanterbara kategorier som t.ex. ålder, kön och bostadsort så skulle det

komstkommissionen «. Även där spelade sociologer en viktig roll, både iledningen och bland forskarna. 
bli lättare att styra utbyggnaden av folktandvården och en kommande tandvårdsförsäkring och nå bästa möjliga välfärdseffekter. Den stora skillnaden i tandstatus mellan äldre kvinnor i socialgrupp III som bodde på landsbygden och yngre medelklassmän i storstäderna var ett sådant direkt reformpolitiskt argument. Här kunde en enkel korstabulering vara direkt relevant för reformpolitiken.

Men vad berättigar här användandet av kategorin reformobjekt? "Reformobjektet" var inte den enkla korstabellen. Det var snarast den förfinade uppdelningen utifrån individbaserade data, dvs att själva kartläggningens form gjorde den användbar. Den nya tekniken gjorde nya förhållanden vetbara och gjorde det möjligt att finna mera precisa former för ingrepp. ${ }^{9}$ Det var levnadsvillkorens differentierade fördelning, denna av forskningen framskapade tankekonstruktion, som blev reformobjektet. Begreppen fördelning, resurs, och arena blev tillsammans med nya mättekniker ett nytt och samtidigt tillämpbart vetande.

På ett mera generellt plan innebar etable-

9 En viktig effekt av den tillämpade sociala forskningen är att både begrepp och nya metoder utvecklas. Från naturvetenskapens historia vet vi hur upptäckten av nya mätinstrument revolutionerat vetandet (alltifrån teleskopet och mikroskopet). I samhällsforskningen är folkräkningarna, panel-analysen, de nya statistiska bearbetningsteknikerna som tar fram nya slags samband exempel på att nya tekniker gör nya problemlokaliseringar och klassificeringar möjliga. Ett välkänt exempel är utvecklingen av arbetskraftsundersökningarna och själva begreppet "labour force» som har haft stor betydelse för utformningen av den moderna arbetsmarknadspolitiken. randet av levnadsnivåforskningen en transformation av fattigdomsforskningen. Det blev möjligt att upprätta en systematisk och ingreppsrelevant katalog av specifika problem som skulle kunna hanteras med sociala reforminsatser, insatser som via den politiskt-administrativa strukturen kunde översättas till adekvata och genomförbara åtgärder. Därigenom kunde de fattigdomsalstrande mekanismerna (i princip) bli föremål för modifikationer och ingrepp. Låginkomstutredningen betonade t.ex. arbetslöshetens och de låga lönernas roll för den låga levnadsstandarden. Detta kunde användas som argument för hög och stigande sysselsättningsgrad (dvs som mål för arbetsmarknadsoch sysselsättningspolitik) och för en (facklig) politik att dränera låglöneträsket. ${ }^{10}$

Den analytiska preciseringen och dekomponeringen av "fattigdom" som brist på olika slags resurser på ett antal olika arenor gjorde det möjligt att mera precist kunna mäta och avgränsa fattigdomens olika komponenter. Denna uppdelning i olika komponenter och till dem svarande "resurser" gjorde det möjligt att länka de problematiska sociala förhållandena till möjliga insatser från myndigheterna. Levnadsnivåforskning-

10 Det finns flera intressanta skillnader mellan den engelska fattigdomsundersökningen av Peter Townsend m.fl. Poverty in the UK från 1979 och de nordiska levnadsnivåundersökningarna. Begreppsligt visar det sig $\mathrm{i}$ betoningen av på låga inkomster som problem respektive fattigdom. Den svenska utredningen institutionaliserades i fortsatta levnadsnivåundersökningar vid SOFI (till en början under Sten Johanssons fortsatta ledning). Vidare byggde Statistiska Centralbyrån upp sina undersökningar om levnadsförhållanden (ULF-statistiken). Något motsvarande skedde inte i Storbritannien. 
en var möjlig att anpassa efter de olika myndigheternas och organens verksamhetsområden. Bostadsförhållanden, hälsa, tandstatus, skolutbildning etc är delaspekter som gör problemen hanteringsbara. Fördelning, resurser och arenor passar in i uppdelningen mellan olika myndighetsorgan.

Men nya vetandeformer kan också leda till utvecklingen av nya hanteringssätt och att nya institutioner och myndigheter upprättas. När maktförhållanden och resursfördelningen mellan könen i linje med dominerande rättvise- och jämlikhetsideologier via den tidiga kvinnorörelsen och samhällsforskningen översätts till målet om jämställdhet så görs den hanterbar som offentlig politik. I detta fall kom nya lagar och nya myndigheter (som JÄMO) att läggas till statens ingreppsrepertoar.

\section{"Problem-vetande-åtgärd" eller nåtgärd-vetande-problem»?}

Hittills har utgångspunkten varit att problemidentifiering, kunskapsgenerering och lösningsförslag har följt varandra enligt sekvensen problem-vetande-åtgärd. Först ett problem, sedan nya vetandetekniker och ny kunskap som gör nya ingrepp och politiska åtgärder möjliga.

Begrepp, data och insamlingstekniker inom den tillämpade socialvetenskapliga forskningen har utvecklats eller skapats $i$ policyrelevant syfte. I den mån nya kunskaper och data har upppkommit som effekter av att myndigheterna har samlat in statistik och uppgifter av olika slag så framstår denna kunskapsutveckling främst som en reaktiv process.

Den tillämpade sociala forskningens sek- vens ser ut på följande sätt:

(I) Problemlokalisering -> kunskap -> handlande $\rightarrow$ resultat $->$ utvärdering $\rightarrow$ ny kunskap-> justering av handlandet.

Går vi mera i detalj kan vi lyfta fram olika led i denna sekvens. Det första ledet går från problemlokalisering till systematisk kunskap. Vi kan här skilja mellan

- observation/lokalisering av problematiska eller icke önskvärda omständigheter

- identifiering och beskrivning av dessa som samhälleliga problem

- förklaring av problemens art, spridning, uppkomst- och återskapande-villkor, inklusive skapandet av ett samhällsvetenskapligt kunskapsobjekt.

Det andra ledet i den rationalistiska sekvensen är att vägen från kunskapsobjekt till policyrelevans går via konstruktion av ett reformobjekt. Därmed upprättas en såväl begreppslig som institutionell koppling mellan kunskapsobjekt och myndighetshantering.

Det tredje ledet utspelas inom myndighetens sfär och innefattar åtgärdsprecisering, policy-implementering och resultatet, inklusive utvärdering av resultaten. ${ }^{11}$

Vi har här beskrivits den tillämpade socialforskningens idealtypiska sekvens. Alla de olika leden finns inte i alla konkreta fall; ordningen mellan dem kan se annorlunda ut. De politiska och administrativa målen är olika i olika samhällen och i olika epoker.

11 En reform och de åtgärder den ger upphov till kan evalueras i relation till mål om levnadsstandardens utveckling, fördelningseffekter etc. Men den kan också analyseras utifrån den roll den har för att öka eller minska en samhällsordnings legitimitet. 


\section{Kunskap som aitgärdseffekt}

Ett andra perspektiv på relationen mellan problem-vetande-åtgärd är att det är åtgärder och rutinerna som skapar kunskap och begrepp. Maktutövning, rutiner och åtgärder skapar systematisering och klassifikationer som får form av vetande - och ett vetande som i sin tur formar och förstärker institutioners agerande.

En mängd forskning visar att åtgärderna och verksamheten, dvs myndigheternas maktutövning och förvaltningens praktik för det första ger upphov till nya former av vetande och inte minst löpande skapar nya klassifikationer av individer, beteenden och handlingar och utvecklar dessa till ordnande och handlingsstyrande begrepp. Detta perspektiv har poängterats i senare års kritiska sociala tänkande och har starkt formats av Michel Foucaults resonemang om diskurser, om förhållandet mellan maktutövning och vetandeformer. Foucaults teori om förhållandet mellan makt och vetande inom institutioner kan ses som en allmän formulering av synen på kunskap som en effekt av maktutövning och åtgärder (Foucault 1983, 1987; Sunesson 1987).

Myndigheters och företags, och mer generellt organisationers, maktutövning och praktiska rutiner ger upphov till klassificerings- och sorteringsbegrepp som formar föreställningarna om organisationernas verksamhet och de människor och förhållanden som dessa organisationer hanterar. Existerande förvaltningsstrukturer och sätt att arbeta kan leda till en särskild slags identifiering och beskrivning av förhållanden, av beteenden eller grupper av individer som problem eller som problematiska.

När det är åtgärderna och den organisa- toriska praktiken som driver fram klassificeringar och därmed begrepp som i vetandets form kan påverka nya handlingar och praktiker kan vi teckna skeendet i form av följande sekvens:

(II) Myndighetens praktik $\rightarrow$ åtgärdsformer $>$ klassifikationer $>$ vetande $>$ nya praktikformer/ätgärder.

Utifrån denna andra sekvens kan vi vända på förhållandet mellan åtgärder, vetande och sociala problem. För de som i den sociala konstruktivismens anda arbetar utifrån denna andra sekvens är det så att »sociala problem« skapas genom maktutövning, t.ex. genom myndigheternas ingrepp. Utan maktingripande finns, eller $i$ ännu strängare form, uppkommer inget "socialt problem".

Tankegången är i princip följande. Den intellektuella och administrativa systematiseringen ger utifrån själva maktutövningens logik upphov till de begrepp och kategorier som skapar problemen. Åtgärderna och klassifikationerna s.a.s. "driver fram" handlandet och därmed ıskapar» de förhållanden och de kategorier som får materiell och social gestalt. Det sker genom processer som stämpling, genom formning av omgivningens uppfattning av vissa individer, beteenden och handlingar och därtill av de utpekades och åtgärdades självbild. Detta är de sociala mekanismer varigenom klassifikationerna, ingripandena och åtgärderna kan skapa "sociala problem".

I detta andra perspektiv är det snarare åtgärderna - och deras konsekvenser - som generar problemen, än att det är problemen som leder till åtgärder. Ett sådant perspektiv har visat sig vara fruktbart för en kritisk reflexion över t.ex. sociala myndigheters praktik i förhållande till bostadslöshet ska- 
par å ena sidan ett nytt segment på bostadsmarknaden med inskränkta rättigheter för de boende, och föreställningar hos sociala myndigheter och bostadsföretag att en växande grupp av människor inte är »kapabla att klara ett eget boender. När den sekundära bostadsmarknaden väl är etablerad återskapas också den grupp av människor som kan hysas däri, främst genom åtgärder och rättighetsinskränkningar som sociala myndigheter och bostadsföretag genomför (Sahlin 1996).

\section{Konklusion}

De ovan nämnda relationerna mellan problem-vetande-ingrepp fångar två centrala aspekter av kategorin »sociala problem" (som åtgärdsdrivande och som åtgärdseffekt) och två olika perspektiv på förhållandet mellan vetande och myndighetshandlande (den rationalistiska ingreppslogiken respektive den kritiska observationen av faktiska, önskade som oönskade, avsedda såväl som icke avsedda effekter). Socialvetenskapen liksom den sociologiska analysen av välfärdsstaten inrymmer både dessa perspektiv.

Låt oss återknyta till det som i inledningen sades om sociologins och socialvetenskapen relation till de sociala problemen. Sociala problem genererar under bestämda förutsättningar vetande, samtidigt som åtgärder och vetande under andra förutsättningar kan generera nya slags sociala problem. Historiskt har den första sekvensen haft störst betydelse för den moderna socialvetenskapens och sociologins utveckling. I dagens socialvetenskap är de två sekvenserna komplementära. De är det som sätt att analysera förhållandet mellan väl- färdsstaten, de sociala förhållanden och problemen. De representerar därtill olika sätt att analysera förhållandet mellan kunskap och maktutövning, mellan vetande och politik, mellan samhällsvetenskap och organisatoriskt handlande.

Men de kan också flätas in i varandra. Policy-tillämpning i den rationalistiska sekvensen leder till åtgärder, varur i sin tur nya hanteringssätt, klassifikationer och begrepp formas. Ett begrepp eller en klassificering som uppkommer i den åtgärdsdrivna sekvensen och en kritisk diskurs kan också "flyttas" över till den rationalistiska (ett exempel är begreppet »utslagningu).

\section{Från reformobjekt till ingreppsobjekt}

I den samhälleliga praktiken uppstår ständigt nya problem och problemfält. Behovet av "reformobjekt « dvs av policy-relevant forskning återföds löpande om än med olika målföreställningar och politiska förtecken.

«Reformobjekt« är ett begrepp som å ena sidan vetter mot myndigheterna och ingripandets praktik, men det vetter också mot den kritiska distansens praktik. Reformobjekt är en specifik variant och en undergrupp av en bredare kategori som vi kan kalla »kunskapsobjekt för ingripande«. På samma begreppsliga plan som reformobjekt finns t.ex. »kritikobjekt« eller »polemikobjekt«.I en svensk kontext skapar såväl en radikal tradition som en nyliberal tankeform "kritikobjekt«, dvs systematiska former av kategoriseringar och vetande som kan översättas till handlingsformer. Och häri spelar begrepp, teorier och grundantaganden från olika social- och samhällsvetenskapliga traditioner en central roll. 


\section{Referenser}

Abrams, Philip 1968, The origins of British sociology: An essay with selected papers. Chicago: Chicago univ. Press

Abrams, Philip 1982, Historical Sociology.. Ithaca: Cornell Univ. Press.

Ahrne, Göran 1971: Hushållsarbete och dubbelarbete. Stockholm, Allmänna förlaget.

Alber,Jens 1982, Vom Armenhaus zum Wohlfahrtsstaat, Frankfurt: Campus Verlag.

Arnman, Göran \& Jönsson, Ingrid 1986: Olika för olika.Aspekterpå svensk utbildningspolitik. Lund,Arkiv förlag.

Arnman, Göran och Jönsson, Ingrid 1983, Segregation och svensk skola, Lund, Arkiv förlag.

Bondesson, Ulla 1974, Fången ifängsamhället, Stockholm:Norstedt.

Castel, Robert 1995, Les métamorphoses de la question sociale. Paris, Fayard

Ds 1980:9, Prostitutionen i Sverige I-II. Stockholm.

Erikson, Robert \& $\AA$ berg, Rune 1984 (red) Välff̈rdi förändring. Lernadsvillkori Sverige 1968-1981. Stockholm:Prisma.

Erikson, Robert \& Jonsson, Jan O. 1994 Sorteringen i skolan studier av snedrekryteringoch utbildningens konsekvenser(red.):Stockholm; Carlsson

Erikson, Robert 1971 Uppväxtförhållanden och social rörlighet ,Stockholm Allmänna förl. 1971

Erikson, Robert och Åberg, Rune (red.) 1984, Välfärd iförändring, Stockholm:Prisma.

Forskningsberedningen 1996, Ärsvenskforskning samhällsrelevant? Diskussionsinläggom forskning från ledamöter i regeringens forskningsberedning.Stockholm:Utbildningsdepartamentet.

Foucault, Michel 1083, Vansinnets historia.Lund: Arkiv förlag.

Foucault, Michel 1987, Övervakningoch straff. Lund:Arkiv

Fridjónsdóttir, Katrín red 1987 Om svensk sociologi historia:problemoch perspektiv Stockholm Carlsson.

Fridjónsdóttir, Katrin (red.) 1990, Svenska samhällsvetenskaper: utvecklingslinjer, problem, perspektiv Stockholm Carlsson

Fritzell, Johan \& Lundberg, Olle (red.) 1994:

Vardagens villkor. Levnadsförhållanden $i$

Sverige under tre decennier Stockholm:

Bromberg.

Fritzell,Johan \& Lundberg, Olle 1993 Ettförlorat ellerförlovat årtionde? Välfärdsutvecklingen mellan 1981 och 1991. Stockholm: Institutet för social forskning.

Garraty, John A. 1978, Unemployment in history, economic thought and public policy. New York

Gesser, Bengt 1971, Rekryteringen till universitet och högskoloriSverigeiSOU 1971:61. Stockholm:SOU

Gesser, Bengt 1985, Utbildning,jämlikhet, arbetsdelning. Lund:Arkiv

Gullberg,Anders 1972 Till den svenska sociologins historia. Stockholm:Unga filosofer.

Habermas, Jürgen 1981, Theorie des kommunikativen Handelns Frankfurt am Main:Suhrkamp.

Heinsohn, Gunnar \& Steiger, Otto 1982 Människoproduktionens historia. Allmän befolkningsteori för den rya tiden. Lund:Arkiv förlag.

Hetzler,Antoinette, Eriksson, Kjell E. 1983 Arbetsskadeförsäkringens tillämpning. En rättssociologisk studie.Lund, Rättssociologiska inst.

Hinkle, Roscoe C. \& Hinkle, Gisela J. 1954 The development of modern sociology, its nature and growth in the United States. New York.

Hinkle, Roscoe C. 1980, Founding theory of American sociology 1881-1915 Boston: Routledge \& Kegan Paul.

Hydén, Håkan 1978 Rättens samhälleliga funktioner. Lund, Studentlitteratur.

Hydén, Håkan 1984 Ram ellerlag? om ramlagstiftningoch samhällsorganisation. Stockholm:Liber/Allmänna förl.

IESS 1968, "The Early History of Social Research"i The International Encyclopedia of Social Sciences vol 15, ss. 36 -53 (förf. Bernard Lécuyer \& Anthony Oberschall.) NewYork\&London.

Johansson, Lena 1970 Utbildning-resonerande del.Stockholm:Allmänna förlaget.

Johansson, Lena 1971 Utbildning-empirisk del. 
Stockholm: Allmänna förlaget.

Johansson, Sten 1970a Om levnadsnivåundersökningen utkast till kapitel 1 och 2 ibetänkande att avgivas av Läginkomstutredningen Stockholm Allmänna förl.

Johansson, Sten 1970b Den vuxna befolkningens hälsotillstånd. Stockholm: Allmänna förlaget.

Johansson, Sten 1970c Den vuxna befolkningens kostvanor. Stockholm: Allmänna förl.

Johansson, Sten 1971 Politiska resurser. Om den vuxna befolkningens deltagande i de politiska beslutsprocesserna. Stockholm Allmänna förl.

Kern, Horst 1982 Empirische Sozialforschung: Ursprünge, Ansätze, Entwicklungslinien München: C.H. Beck.

Lange, Friedrich Albert 1875, Die Arbeiterfrage: Ihre Bedeutung für Gegenwart und Zukunft. 3. Aufl. Winterthur, 1875.

Liljeström, Rita 1975, Samhället och barns utveckling. SOU 1975:31 Stockholm: Liber Förlag

Liljeström, Rita 1973, Uppväxtvillkor. Samspelet mellan vuxna och barn i ett föränderligt samhälle. Stockholm: Allmänna förlaget.

Lilliestam, Åke 1960 GustafSteffen, samhällsteoretiker och idépolitiker Göteborg: Akademiförlaget-Gumperts.

Madge, John The origins of scientific sociology $\mathrm{New}$ York 1962

Merton, Robert K. \& Nisbet, Robert A. (red.) 1961 Contemporary social problem an introduction to the sociology of deviant behavior and social disorganization. New York: Harcourt, Brace.

Mills, C. Wright 1943/1963, "The Professional Ideology of Social Pathologists", i Power, politics and people - the collected essays of C. Wright Mills. (red.) Irving Louis Horowitz. New York: Oxford Univ. Press. 1963

Mitzman, Arthur 1973, Sociology and estrangement - three sociologists of imperial Germany. [Ferdinand Tönnies, Werner Sombart, Robert Michaels]. New York.

Myrdal, Alva \& Myrdal, Gunnar 1934, Kris i befolkningsfraigan. Stockholm: Bonnier.

Nisbet, Robert A. 1967, The Sociological Tradition, London: Heinemann.

Oberschall, Anthony 1965, Empirical social re- search in Germany, 1848-1914 Paris: Mouton. Oberschall, Anthony (red.) 1972, The establishment of empirical sociology: Studies in continuity, discontinuity, and institutionalization. $\mathrm{New}$ York

Olofsson, Gunnar 1979, Mellan klass och stat. Lund: Arkiv förlag.

Olofsson, Gunnar 1995, Klass, rörelse, socialdemokrati. Essäer om arbetarrörelsens sociologi. Lund: Arkiv förlag

Olofsson, Gunnar (kommande), Stat, marknad, socialpolitik. Essäer om välfärdsstatens sociologi.

Parsons, Talcott 1937, The structure of social action. Astudy in social theory with special reference to a group of recent European writers $\mathrm{New}$ York: Free Press.

Polanyi, Karl 1944/1989 The great transformation [the political and economic origins of our time] Sv. övers. Den stora omdaningenLund: Arkiv.

Ringer, Fritz K 1969 The decline of the German mandarins. The German academic community, 1890-1933. Cambridge, Mass: Harvard Univ. Press.

Sahlin, Ingrid 1996 Pågränsen till bostad: avvisning, utvisning, specialkontrakt. Lund: Arkiv förlag.

Schwendinger, Herman \& Schwendinger Julia R. 1974 The sociologists of the chair a radical analysis of the formative years of North American sociology (1883-1922). New York: Basic Books

Sombart, Werner 1908, Sozialismus und soziale Bewegung, 6. verm. Aufl. Jena: Fischer.

Sørensen, Curt 1976 Marxismen og den sociale orden. Kongerslev: GMT

Sunesson, Sune 1985, Andra allt' en uppmaning till socialarbetare Malmö: Liber Förlag.

Sunesson, Sune 1987, "Inledning" till Michel Foucault, Övervakning och straff. Lund: Arkiv förlag.

Sunesson, Sune 1985, Ändra allt! en uppmaning till socialarbetare Malmö: Liber Förlag.

Sunesson, Sune 1985, Ändra allt! en uppmaning till socialarbetare Malmö: Liber Förlag.

Therborn, Göran 1976, Science, class and society. On the formation of sociology and historical ma- 
terialism. London, NLB.

Townsend, Peter 1979, Poverty in the UK. London:

Penguin.

Wagner, Peter 1990, Sozialwissenschaften und

Staat. Frankreich, Italien, Deutschland 1870 -

1980. Frankfurt, Campus-Verlag

Widerberg, Karin 1980 Kvinnor, klasser och lagar

1750-1980. Stockholm: Liber Förlag.

Vogel, Joachim 1987a, Ojämlikheten i Sverige. Ut

veckling och nuläge Stockholm: Statistiska cen- tralbyrån.

Vogel, Joachim 1987b, Det svenska klassamhället klasstruktur, social rörlighet och ojämlikhet. Stockholm: Statistiska centralbyrån 1987

Zeitlin, Irving M. 1968, Ideology and the development of sociological theory Englewood Cliffs: Prentice Hall.

Østerberg, Dag 1988, Metasociology - an inquiry into the origins and validity of social thought. Oslo, Norwegian University Press.

\section{Summary \\ Social science and social problems}

The rise of empirical social research and sociology as a scientific discipline is closely related to the role of social problems, i.e. the role of poverty, unemployment, insecurity as well as problems of adaptation and adjustment in the late 19th century and the first decades of the 20th. Interpretations and explanations of "social problems" were crucial for the rise of social research in Europe and in the USA.

Applied social science in this field aims at linking explanation and intervention, mainly in the form of decisions taken by the state and other public authorities. The cognitive operation undertaken by applied social science is the construction of a specific set of "objects of knowledge", here defined as "objects for intervention", or specifically in the Swedish case, "reformoriented knowledge objects". This is discussed in more detail by taking up the fate of poverty research, which in the 1960s and 1970s was transformed into the paradigm of social indicators and level-of-living studies. It is argued that the kind of explanation sought, the methodology used and the intervention made possible were closely linked to each other, a link made possible by "knowledge objects for intervention", developed by social scientists.

A rationalistic understanding of the role of social problems, feeding into the political process by being reworked by applied social science, is then contrasted to another interpretation of "social problems", which is inspired by Foucault and some social constructivists. Here "social problems" becomes a category that is seen as originating as the social effects of power relations, power being primarily in the hands of public officials and institutions. Power includes control over resources as well as the power of classification of individuals, their behaviour and actions.

It is argued that these two perspectives on the relation between social science and social problems are complementary and that both conceptions are present in the sociology of the welfare state. These two conceptions are intertwined, which is shown by the observation that concepts and interpretations can "travel" between them. 


\section{Vad}

\section{vet vi om}

\section{framtiden?}

Vem vet vad våra barnbarn kommer att säga om 90-talets vård av barn, gamla, missbrukare eller utvecklingsstörda?

All utveckling kräver kunskap! Nu kan Du bidra till kunskapsutvecklingen genom att stödja Socialforskningsfonden.

Socialforskningsfondens mål är att främja utveckling av social forskning, verka för utbyte av kunskap mellan forskning och fält, förbättra villkoren för forskning och forskarutbildning och verka för internationellt utbyte inom olika områden

\section{Socialforskningsfondens postgironummer är} 900611 - 5.

Ange gärna om Du vill stödja något speciellt forskningsomráde.

\section{Socialforskningsfonden} har initierats av Förbundet för Forskning i Socialt arbete (FORSA)

Socialforskningsfonden 